\title{
Evaluating the effectiveness of in-service training program of Amhara Public Health Institute Dessie Branch, Northeast Ethiopia: a concurrent nested mixed quantitative/qualitative facility based cross sectional study
}

Seid Legesse Husen ( $\nabla$ seidlegese2012@gmail.com )

Amhara Public Health Institute https://orcid.org/0000-0002-7177-9475

Tefera Alemu Marefiaw

Amhara Public Health Institute

Mulugeta Tasew Hailie

Amhara Public Health Institute

Birtukan Shiferaw Ayalew

Amhara Public Health Institute

Zerfie Tadesse Reta

Amhara Public Health Institute

Semagn Amare Desalew

Amhara Public Health institute

Minwuyelet Maru Temesgen

Amhara Public Health Institute

Research

Keywords: Effectiveness, Evaluation, In-service training, APHI

Posted Date: August 6th, 2020

DOI: https://doi.org/10.21203/rs.3.rs-52966/v1

License: (a) (i) This work is licensed under a Creative Commons Attribution 4.0 International License.

Read Full License 


\section{Abstract \\ Background}

In-service training programs should be evaluated and modified regularly to provide quality health services. However, in Ethiopia, there is no published evidence about its effectiveness. Therefore, we evaluated the effectiveness of in-service training program of Amhara Public Health Institute Dessie Branch (APHI) using the Kirkpatrick model.

\section{Methods}

In October 2019, a concurrent nested mixed quantitative/qualitative, facility-based cross-sectional study was conducted among 107 stakeholders from 22 randomly selected east Amhara government health facilities. The qualitative part also involved all this key stakeholder interviews. Data was collected using a semi-structured questionnaire through face to face interview. Epi data manager and Microsoft Excel 2016 software's were used for data entry and analysis respectively. The major qualitative findings were narrated and summarized based on thematic areas to supplement the quantitative findings.

\section{Results}

A total of 107 laboratory professionals working in 22 health facilities were interviewed with a response rate of $97.3 \%$. At reaction level, $82.1 \%$ of participants strongly agreed/agreed with the course structure, training contents and learning tools. Likewise, $85.4 \%$ of them strongly agreed/agreed on trainer's knowledge and their communication skills. Besides, $93.1 \%$ of them stated an improvement in knowledge and skills after attending training. Yet, only $65.6 \%$ of participants transferred their knowledge and skills in to practice. Regarding the training set ups and environment, $45.1 \%$ of the respondents strongly disagreed/disagreed with the training hall, toilet, café, financial process, accommodation perdiem and, tea \& snacks.

\section{Conclusion and recommendations:}

Generally speaking, the laboratory in-service training program of APHI was more or less effective. Our finding suggests regular monitoring and evaluation of training events based on a standard set of performance indicators. Furthermore, the institute is mandated to create a conducive learning environment and well established training set ups for trainees.

\section{Introduction}

In-service training is one of the commonly used strategies to improve health workers knowledge, skills and behaviors on new health approaches and technologies [1, 2]. Its main objective is to capacitate 
health workers with the ability to deliver quality health services to all segments of the population [3]. To meet its objective, periodic evaluation of a training program could be conducted to identify major program strengths and weaknesses [4]. This helps training organizers to learn from their previous experiences; to know which stages of the training were successful and which not, or whether the approach to the training should be changed or not $[5,6]$. After all, the results of evaluation should be used to modify the contents and conducts of a training program [4].

In Ethiopian healthcare setting, laboratory professionals are responsible for performing routine as well as highly specialized tests to diagnose and/or aid in the treatment of diseases, preventing and solving problems with results, specimens, or instruments and communicating test results to the pathologist or clinicians [7]. Therefore, they need to be trained on specialized instrumentation and techniques to analyze patients' samples, such as blood, urine, stool, body fluids, tissues and cells that might indicate cancer or other diseases [8]. Thus, the Amhara Public Health Institute Dessei Branch (APHI) in collaboration with partners is providing different capacity building trainings to laboratory and other health professionals in Amhara region.

However, training by itself cannot solve structural, organizational, or policy problems within an organization, although supportive supervision and the use of motivational strategies can help sustain performance improvement derived from training. The training evaluation also allows the identification of factors that restrain or contribute to a better performance of the trained health professionals, suiting the training actions to the organizational needs $[9,10]$.

In Ethiopia, health care organizations including APHI spend substantial amounts of time, effort, and funding on quality of care improvement trainings, yet there is no published evidence about the effectiveness of in-service trainings. Therefore, evaluation of in-service training programs of Amhara Public Health Institute Dessei Branch is found to be important as it can provide information on the effectiveness of training services that would alert to plan for enhanced quality of trainings, give attention for better training programs. Also it highlights the major strengths and weakness in the training stages and the trainer institute.

\section{Methods Of Evaluation}

\section{Evaluation design and period}

In October 2019, a concurrent nested mixed method, facility-based cross-sectional study was conducted to assess the effectiveness of laboratory in-service training program of APHI.

Study area and setting: Amhara Public Health Institute Dessie Branch (APHI) was established in 1982 as a regional laboratory research center and renovated as a branch public health institute in 2016. It is located in Dessie town, eastern Amhara, $401 \mathrm{~km}$ far from Addis Ababa (the capital city of Ethiopia) to the northeast direction and $490 \mathrm{~km}$ from Bahir-Dar (capital city of Amhara regional state). The institute has 
three main directorates; namely laboratory, research \& technology transfer and public health emergency management[11].

The laboratory directorate provides technical support to health facilities found in the six zones, serves as in service training site for capacity building trainings, referral and specialized laboratory test site, perform public health lab for epidemic prone disease, external quality assurance activities, mentorship and accreditation. In these regard, the institute has the mandate to establish and maintain a high quality and sustainable laboratory system throughout the sub region. It also delivers quality and accessible laboratory services related to the occurrence, causes, prevention and diagnosis of major diseases of public health importance and to establish and support National Laboratory Quality Assurance programs and systems[12].

To realize it mission, the institute benefits from the generous support of the Ethiopian and regional government and various national and international organizations. Some of the organizations that support the institute includes the World Health Organization through its Global Fund, Centre for Disease Control, Japan International Cooperation Agency, International Center for AIDS Care and Treatment Programs (I-CAP) and various non-governmental organizations through joint projects.

\section{Sample size and sampling technique}

Firstly, out of 30 external quality assurance (EQA) sites, 22 were randomly selected to represent the sub region. Then, five laboratory professionals from each health facilities were randomly selected, making a final sample size of 110 respondents. The qualitative part also involved all this key stakeholder interviews. All participants were laboratory professionals with a minimum of one-year work experience and who had ever attended on at least one laboratory in- service trainings in Amhara Public Health Institute Dessie Branch within the past two years.

\section{Data collection}

Data was collected using a semi-structured questionnaire through face to face interviews. The questionnaire had both open-ended and close-ended questions. Respondent's opinion, suggestions and comments were received through key stakeholder interviews. The questionnaire covered information on laboratory training profiles, training content and tool, training set up and training impact. Our respondents were laboratory personnel's from selected health centers and hospitals. The data collectors were the investigators themselves.

\section{Data quality assurance}

To minimize the subjectivity of responses from stakeholders, the investigators themselves participated as data collectors. During the session of each visit, we briefed the respondents about the purpose of the assessment, which was to evaluate the effectiveness of in-service training program of APHI; not merely the individual's performances. In addition, respondents were asked to feel open and comfortable to give 
their opinions, suggestions and comments that can help to improve in service training programs and future laboratory services.

\section{Data analysis}

All responses were graded as 'strongly agree, agree, not decided, disagree, strongly disagree and yes or no, except for the open-ended questions. Data completeness was checked on daily basis and the quantitative data entry was done through Epi data manager software and exported to Microsoft Excel worksheet 2016 for analysis. Data analysis was done at four levels, i.e. (i) Trainees reaction towards training, (ii) Trainers knowledge on the course \& their communication skills, (iii) Learning of training content, (iii) Changes in job behavior after attending training (iv) Training set ups, benefits and financial issues. Descriptive statistics were computed to describe the data. Then the major qualitative findings were narrated and summarized based on thematic areas to supplement the quantitative findings.

\section{Operational definitions}

\section{In-service training}

Different, short term, practical training courses given by APHI for laboratory professionals working at health facilities to scaling up their knowledge and skills.

\section{Training effectiveness}

For each levels of evaluation, effectiveness is judged as not effective when values fall less than 50th quartile, partially effective between 50th and 75th quartiles and effective above 75th quartiles.

\section{Results}

\section{Socio demographic characteristics of respondents.}

A total of 107 laboratory professionals who were working in 22 selected health facilities (18 hospitals and 4 health centers) were interviewed which makes the response rate 97.3 percent. The proportion of male respondents was $60.7 \%$. The age of the participants ranged from 20 to 49 years; $42 \%$ were between 25 and 29 years old. Majority of the respondents are diploma holders (53.3\%) while nearly $44 \%$ are first degree professionals. Regarding respondents work experience, $44 \%$ has one up to three years' experience whereas $34.6 \%$ of them had more than five years work experience and the rest $21.5 \%$ are in between three and five year experiences. Majority (84.1\%) of the respondents are working in hospital and the rest $15.9 \%$ are in health centers (Table 1). 
Table 1

Socio demographic characteristics of respondents, northeast Ethiopia, October $2019(\mathrm{~N}=107)$

\begin{tabular}{|c|c|c|}
\hline Variables & Category & Number (\%) \\
\hline \multirow[t]{2}{*}{ Sex } & Male & $65(60.7)$ \\
\hline & Female & $42(39.3)$ \\
\hline \multirow[t]{4}{*}{ Age category } & $18-24$ years & $38(35.5)$ \\
\hline & $25-29$ years & $45(42.1)$ \\
\hline & $30-34$ years & $15(14)$ \\
\hline & $>=35$ years & $9(8.4)$ \\
\hline \multirow[t]{3}{*}{ Work experience } & $1-3$ years & $47(43.9)$ \\
\hline & $3-5$ years & $23(21.5)$ \\
\hline & $>5$ years & $37(34.6)$ \\
\hline \multirow[t]{3}{*}{ Level of education } & Diploma & $57(53.3)$ \\
\hline & Degree & $47(43.9)$ \\
\hline & Masters & $3(2.8)$ \\
\hline \multirow[t]{2}{*}{ Health facilities involved } & Hospitals & $18(81.8)$ \\
\hline & Health centers & $4(18.2)$ \\
\hline \multirow[t]{2}{*}{ Respondents workplace } & Hospital & $90(84.1)$ \\
\hline & Health center & $17(15.9)$ \\
\hline
\end{tabular}

\section{Distribution of in service training for laboratory professionals}

As depicted in Table 2, about $53.3 \%$ of laboratory professionals were trained on new HIV test algorism, $52.3 \%$ on tuberculosis fluorescent microscopy and Ziehl-Neelsen diagnosis, $69.2 \%$ on malaria diagnosis, $26.2 \%$ on gene expert and $69.2 \%$ on laboratory quality management system. On the other hand, only $8.5 \%$, and $6.5 \%$ of laboratory professionals were trained on dry blood spot/viral load sample collection and basic microbiology courses respectively.

Additionally, the qualitative findings showed that training opportunities were almost equally spread across the health facilities and the number of trained professionals seems adequate. However, few of the respondents believed that there was trainee selection bias or selection criteria are not fair from facility to facility and also the calling modality was not appropriate, particularly at zonal health department level. 
Table 2

Distribution of in service trainings received from Amhara Public Health Institute Dessie Branch, northeast Ethiopia, October $2019(\mathrm{~N}=107)$

\begin{tabular}{|c|c|c|}
\hline Type of training & Received & Frequency (\%) \\
\hline \multirow[t]{2}{*}{ New HIV testing algorism } & Yes & $49(45.8)$ \\
\hline & No & $58(54.2)$ \\
\hline \multirow[t]{2}{*}{ Tuberculosis Fluorescent Microscopy \& Ziehl-Neelsen diagnosis } & Yes & $56(52.3)$ \\
\hline & No & $51(47.7)$ \\
\hline \multirow[t]{2}{*}{ Malaria diagnosis } & Yes & $74(69.2)$ \\
\hline & No & $33(30.8)$ \\
\hline \multirow[t]{2}{*}{ Laboratory Quality Management System } & Yes & $57(53.3)$ \\
\hline & No & $50(46.7)$ \\
\hline \multirow[t]{2}{*}{ Strengthening Laboratory Management Toward Accreditation } & Yes & $47(43.9)$ \\
\hline & No & $60(56.1)$ \\
\hline \multirow[t]{2}{*}{ Safety and Biosecurity } & Yes & $43(40.2)$ \\
\hline & No & $64(59.8)$ \\
\hline \multirow[t]{2}{*}{ Anti-retroviral treatment automation } & Yes & $54(50.5)$ \\
\hline & No & $53(49.5)$ \\
\hline \multirow[t]{2}{*}{ Dried Blood Spots specimen for HIV viral load sample collection } & Yes & $9(8.4)$ \\
\hline & No & $98(91.6)$ \\
\hline \multirow[t]{2}{*}{ Sample Referral Linkage } & Yes & $27(25.2)$ \\
\hline & No & $80(74.8)$ \\
\hline \multirow[t]{2}{*}{ Basic Microbiology } & Yes & $7(6.5)$ \\
\hline & No & $100(93.5)$ \\
\hline \multirow[t]{2}{*}{ Gene Expert } & Yes & $28(26.2)$ \\
\hline & No & $79(73.8)$ \\
\hline \multirow[t]{2}{*}{ Internal Audit } & Yes & $20(18.7 \%)$ \\
\hline & No & $87(81.3)$ \\
\hline \multirow[t]{2}{*}{ Compassion, Respectful and Caring Professional } & Yes & 12(11.2) \\
\hline & No & $95(88.8)$ \\
\hline
\end{tabular}




\section{Satisfaction of trainees with the course structure, content and training tools}

Most of the respondents (79.4\%) strongly agreed/agreed that technology/lab equipment and training tools were working properly during the training time and able to provide all the necessarily practices for the course, though $17.8 \%$ of the respondents strongly disagreed/disagreed on this idea. The same proportion of respondents ( $80.4 \%)$ strongly agreed/agreed that the course provided opportunities to practice and would improve their job performance. Moreover, majorities of the respondents (86.9\%) strongly agreed /agreed that the courses outcome was successfully achieved compared to meet their general expectations of the training and the courses gave trainee a clear understanding of the goals and objectives of the training before they started the training (96.3\%).

In agreement with the quantitative finding, most of the respondents in the qualitative in-depth interview believed that the course structure, content and training tools of training were clear and understandable; courses providing opportunities to practice and the contents were in depth enough. Similarly, the availability of laboratory equipment's and tools has been appreciated, especially in the context of Strengthening Laboratory Management Toward Accreditation and Automation trainings. Nevertheless, some of the respondents raise "too short practical session and shortage of necessary machines and equipment's" as a problems regarding course structure, content and training tools. 
Table 3

Distribution of responses on the course structure, content and training tools of trainings in Amhara Public Health Institute Dessie Branch, northeast Ethiopia, October/2019 ( $N=107)$

\begin{tabular}{|c|c|c|c|}
\hline Survey items & $\begin{array}{l}\text { "Strongly } \\
\text { agree" or agree } \\
(\%)\end{array}$ & $\begin{array}{l}\text { "Strongly } \\
\text { disagree" or } \\
\text { disagree (\%) }\end{array}$ & $\begin{array}{l}\text { Not to } \\
\text { decide }\end{array}$ \\
\hline $\begin{array}{l}\text { Goals and objectives clearly stated before you } \\
\text { started the training? }\end{array}$ & $103(96.3)$ & $4(3.7)$ & 0 \\
\hline $\begin{array}{l}\text { Training length was sufficient to deliver the } \\
\text { course? }\end{array}$ & $87(81.3)$ & $20(18.7)$ & 0 \\
\hline Learning aids assisted your training? & $91(85)$ & $13(12.1)$ & $3(2.8)$ \\
\hline $\begin{array}{l}\text { Technology/lab equipment was working properly } \\
\text { during the training or practical session? }\end{array}$ & $85(79.4)$ & 19(17.8) & $3(2.8$ \\
\hline Was the content in-depth enough? & $70(65.4)$ & $32(29.9)$ & $5(4.7)$ \\
\hline Was the course provided opportunities to practice? & $86(80.4)$ & $20(18.7)$ & $1(0.9)$ \\
\hline $\begin{array}{l}\text { Was more than one training style used or was } \\
\text { conducive to my learning style? }\end{array}$ & $88(82.2)$ & $15(14)$ & $4(3.7)$ \\
\hline $\begin{array}{l}\text { Course outcome was successful compared to } \\
\text { meet their expectations? }\end{array}$ & 93(86.9) & 13(12.1) & $1(0.9)$ \\
\hline Cumulative satisfaction score & $82.1 \%$ & $15.9 \%$ & $2 \%$ \\
\hline
\end{tabular}

\section{Trainer's knowledge and skills during training the course}

The proportions of respondents that strongly agreed/agreed on trainer's knowledge about the course content, their communication and delivery skills were nearly similar. Hence, $91 \%$ of respondents strongly agree or agree that trainer's be able to deliver training course's properly and majority of respondents $(88.8 \%)$ strongly agree or agree that trainer's communication skills was able to provide all the information needed for the course. About $86 \%$ of respondents strongly agrees or agrees regarding trainer's knowledge on the course. Yet, $13.7 \%$ of respondents strongly disagrees or disagrees with that of trainer's ability to create participatory and interactive training environment; though $12 \%$ of the respondents are not able to decide on this issue.

Findings from the qualitative part also revealed that majority of respondents acknowledged the trainer's knowledge and skills as a potential to confident the trainers. Others also reported more positive notions of knowledge, skills and their willingness to train based on their praising. In contrary to these, as stated by few of the respondents, some of the problems related to knowledge and skills of trainers includes; undermining of trainee, a few trainers are aggressive, sometimes trainers are none expertise or nonlaboratory professionals, few trainer's presentation style is lecture so better to be entertaining style, trainers did not took training of trainers. 
Table 4

Classifications of trainer's knowledge and skills in Amhara Public Health Institute Dessie Branch, northeast Ethiopia, October/2019 ( $\mathrm{N}=107)$

\begin{tabular}{|llll|}
\hline Survey items & $\begin{array}{l}\text { Strongly agree or agree } \\
(\%)\end{array}$ & $\begin{array}{l}\text { Not to } \\
\text { decide }\end{array}$ & $\begin{array}{l}\text { Strongly disagree or disagree } \\
(\%)\end{array}$ \\
\hline Trainer's delivery skills & $97(91)$ & $7(6.5)$ & $3(2.8)$ \\
\hline $\begin{array}{l}\text { Participatory and } \\
\text { interactive }\end{array}$ & $79(73.8)$ & $13(12.2)$ & $15(14)$ \\
\hline Trainer's knowledgeable & $92(86)$ & $9(8.4)$ & $6(5.6)$ \\
\hline $\begin{array}{l}\text { Trainer's communication } \\
\text { skills }\end{array}$ & $95(88.8)$ & $6(5.6)$ & $6(5.6)$ \\
$\begin{array}{l}\text { Trainer responsive to } \\
\text { questions }\end{array}$ & $96(89.7)$ & $9(8.4)$ & $2(1.87)$ \\
\hline $\begin{array}{l}\text { Trainer preparedness for } \\
\text { class }\end{array}$ & $89(83.2)$ & $10(9.35)$ & $8(7.5)$ \\
\hline $\begin{array}{l}\text { Cumulative score } \\
\text { New Knowledge and skills acquired in the training (Learning } \\
\text { the Contents) }\end{array}$ & $85.4 \%$ & $8.4 \%$ & $6.3 \%$ \\
\hline
\end{tabular}

In this stage, $93.1 \%$ of the trainees strongly agreed/agreed that their knowledge and skills have improved as a result of having attended the training. Likewise, $92.5 \%$ of them strongly agreed/agreed that the practical sessions of the training have really improved their skills and professional competencies.

Table 5

Improvement in trainee's knowledge and skills after attending training in Amhara Public Health Institute Dessie Branch, northeast Ethiopia, October/2019 ( $\mathrm{N}=107)$

\begin{tabular}{|lllll|}
\hline Item description & $\begin{array}{l}\text { Strongly } \\
\text { agree }\end{array}$ & Agree & $\begin{array}{c}\text { Not to } \\
\text { decide }\end{array}$ & Disagree \\
\hline $\begin{array}{l}\text { Do you feel that your knowledge or skills have } \\
\text { improved by taking the training }\end{array}$ & $37(34.6)$ & $63(58.9)$ & $3(2.8)$ & $4(3.7)$ \\
$\begin{array}{l}\text { Do you believe that the practical exercises were good } \\
\text { that actually improved your skill }\end{array}$ & $35(32.7)$ & $64(59.8)$ & $4(3.7)$ & $4(3.7)$ \\
\hline Average item score & $33.7 \%$ & $59.4 \%$ & $3.3 \%$ & $3.7 \%$ \\
\hline
\end{tabular}

\section{Change in job behavior and performance in workplace (Behavioral level)}

At this level of evaluation, $93.5 \%$ of trainees mentioned as if they are applying the knowledge and skills they gained during the training in their workplace and $69.2 \%$ of them tried to qualify other laboratory professionals in their working areas, $68.2 \%$ of them are using the training materials properly. However, 
$73.8 \%$ of the respondents have replied that there is no registration system that indicates trained staffs in the lab unit of their facility and $55.1 \%$ of them also indicated that they didn't assign trained persons to appropriate positions.

\section{Table 6}

Trainees knowledge and skill transfer in to practice in their working facility, northeast Ethiopia, October/2019 ( $\mathrm{N}=107)$

\begin{tabular}{|lll|}
\hline Variables & \multicolumn{2}{l|}{ Response } \\
\cline { 2 - 3 } & Yes & No \\
\hline Were the learned knowledge and gained skills used in a workplace? & $100(93.5)$ & $7(6.5)$ \\
\hline Is the training materials on use/shared to other staffs in your work place? & $73(68.2)$ & $34(31.8)$ \\
\hline Assign trained personnel's on proper work position & $48(44.9)$ & $59(55.1)$ \\
\hline Trying to qualify other health professionals in a work place & $74(69.2)$ & $33(30.8)$ \\
\hline Would you recommend these trainings to a colleague & $88(82.2)$ & $19(17.8)$ \\
\hline Would you consider further training on the topic on your own & $91(85)$ & $16(15)$ \\
\hline Is there registration system that indicate trained staffs in the lab unit & $28(26.2)$ & $79(73.8)$ \\
\hline Identified thematic area for training & $60(56.1)$ & $47(43.9)$ \\
\hline Do you have monitoring and evaluation system & $68(63.6)$ & $39(36.4)$ \\
\hline Organization announce when trained professional change work site & $72(67.3)$ & $35(32.7)$ \\
\hline Average item score & $65.6 \%$ & $34.4 \%$ \\
\hline
\end{tabular}

\section{Training set ups and environment}

More than half of the respondents $(51,4 \%)$, strongly disagreed/disagreed with the training set up (hall, toilet, café) suitability for the training. In the meantime, $46.7 \%$ respondents strongly disagreed/disagreed with accommodation perdeim and or refreshments of the training program. As well, $28.9 \%$ of the respondents mentioned as if the calling modality for the training was inappropriate. Still, $69.2 \%$ of the respondents strongly agreed or agreed on time and season of the training.

The finding from the qualitative part also find out that many of the respondents had a complain concerning training set ups, benefits and financing processes. Thus many of them have been fill discomfort with training hall, toilet, café, financing process, insufficiency of perdiem, and not happy with tea and snacks. As well, some respondents have been disgusted by extended waiting times, guilty words and insults while processing their accommodation perdiem. 
Table 7

Respondents description of training set ups, benefits and finance related factors in Amhara Public Health Institute Dessie Branch, northeast Ethiopia, October/2019 ( $\mathrm{N}=107)$

\begin{tabular}{|c|c|c|c|c|c|}
\hline \multirow[t]{2}{*}{ Item description } & \multicolumn{5}{|c|}{ Response grading } \\
\hline & $\begin{array}{l}\text { Strongly } \\
\text { agree }\end{array}$ & Agree & $\begin{array}{l}\text { Not to } \\
\text { decide }\end{array}$ & Disagree & $\begin{array}{l}\text { Strongly } \\
\text { disagree }\end{array}$ \\
\hline $\begin{array}{l}\text { Training facilities/hall, toilet, café,...) was } \\
\text { suitable for training }\end{array}$ & $4(3.7)$ & $26(24.3)$ & $22(20.6)$ & $38(35.5)$ & $17(15.9)$ \\
\hline $\begin{array}{l}\text { Adequacy of accommodation } \\
\text { perdiem/tea breaks for the training }\end{array}$ & $12(11.2)$ & 20(18.7) & $25(23.4)$ & $40(37.4)$ & $10(9.3)$ \\
\hline $\begin{array}{l}\text { Was training time and season } \\
\text { appropriate? }\end{array}$ & 17(15.9) & $57(53.3)$ & 17(15.9) & 14(13.1) & $2(1.9)$ \\
\hline Way of calling was appropriate & 19(17.9) & $57(53.3)$ & 0 & 12(11.2) & 19(17.7) \\
\hline $\begin{array}{l}\text { Training call was heard in appropriate } \\
\text { time }\end{array}$ & $17(15.9)$ & $65(60.7)$ & 19(17.8) & $6(5.6)$ & 0 \\
\hline Average item score & $12.9 \%$ & $42 \%$ & $15.5 \%$ & $20.6 \%$ & $9 \%$ \\
\hline
\end{tabular}

Overall, the authors have tried to summarize the effectiveness status of each levels of training evaluations. As a result, participant's reaction and their learning events were rated as effective; while post training behavioral change and the training set ups were partially effective. In general, the average cumulative scores of each level of evaluations fall in the fourth quartile (76.2\%). Thus, according to our operational definition, this figure shows as the in-service training program of APHI was more or less effective (Table 8). 
Table 8

Summary table on the effectiveness status of in-service training program of APHI, northeast Ethiopia.

\begin{tabular}{|c|c|c|c|c|}
\hline \multirow[t]{3}{*}{ Major themes /Level of evaluation } & \multirow{3}{*}{$\begin{array}{l}\text { No. of } \\
\text { indicators }\end{array}$} & \multicolumn{2}{|c|}{$\begin{array}{l}\text { Cumulative score derived } \\
\text { from the data (\%) }\end{array}$} & \multirow[t]{3}{*}{$\begin{array}{l}\text { Judgment } \\
\text { level }\end{array}$} \\
\hline & & $\begin{array}{l}\text { Strongly } \\
\text { agree/agree }\end{array}$ & $\begin{array}{l}\text { strongly } \\
\text { disagree/ }\end{array}$ & \\
\hline & & & disagree & \\
\hline $\begin{array}{l}\text { Reaction of trainees towards training ( } \\
\text { Reaction level) }\end{array}$ & 8 & 82.1 & 15.9 & Effective \\
\hline Trainer's knowledge and skills & 6 & 85.4 & 6.3 & Effective \\
\hline $\begin{array}{l}\text { New knowledge and skills acquired } \\
\text { (Learning level) }\end{array}$ & 2 & 93.1 & 3.7 & Effective \\
\hline $\begin{array}{l}\text { Change in job behavior and } \\
\text { performance (Behavioral level) }\end{array}$ & 10 & 65.6 & 34.4 & $\begin{array}{l}\text { Partially } \\
\text { effective }\end{array}$ \\
\hline Training set ups \& environment & 5 & 54.9 & 29.6 & $\begin{array}{l}\text { Partially } \\
\text { effective }\end{array}$ \\
\hline Average item score & & $76.2 \%$ & $18 \%$ & Effective \\
\hline
\end{tabular}

\section{Discussion}

This study has tried to assess the effectiveness of Amhara Public Health Institute training programs using the Kirkpatrick models of training evaluation. Thus, in the first level of evaluation, our participants were motivated and reacted positively on the course structure, content and training tools, which has also documented in a study from Egypt [13]. Our finding at this level might indicate excellences in training module preparation, training need assessment and trainee recruitment.

Regarding trainer's knowledge and skills on the course content, most participants point out that trainer's knowledge about the course content, their good communication and delivery skills were adequate to provide all the information needed for the course. This indicates the effectiveness of "training of trainers" program that qualified trainers with the technical requirements of a good trainer. Besides, allocating adequate number of trainers with sufficient training time, will allow to entertain different ideas in a classroom which provides more discussion opportunities to trainees to acquire all the knowledge and skill competencies of the training. Conversely, the allocation of non-competent trainers in the present study could be attributed with trainer's knowledge gap and/or lack of expertise or intentionally assigned by training organizers; just for the seek of individual benefits or due to lack of experienced trainers. These comments may indicate a weakness in providing training to address actual training gaps.

In the second level of our evaluation, majority of our participants really stated an improvement in their knowledge and skills after training. In agreement to this, a study done in Sweden and Sri Lankan also pointed out the effectiveness of training in improving trainee's knowledge and skills [10,14]. Moreover, 
another systematic review emphasized the importance of training to health professionals in order to enrich their pre-existing knowledge and skills[15].

Moreover, our evaluation at the behavioral level asserted that the knowledge and skills they gained during the training has positively impacted their work performance in majority of the cases. This result is also evidenced in a recent systematic review on essential newborn care training that suggests improvements in delivery room newborn care practices as compared with usual care[16]. In this phase, our finding implies the success of APHI training programs to achieve its goal deeming that the success at behavioral level will leads to result.

Furthermore, nearly half of the trainees declared that the training environments were not suitable and appropriate for learning. Thus many of them have been fill discomfort with training halls, toilets, café, the financing process and insufficiency of perdiem, and not happy with tea and snack refreshments. The unfavorability her is partially explained by the fact that the training institute is currently working in a temporary and non-standardized building blocks with confined and limited classrooms. Unless otherwise these kinds of problems are identified and resolved early, they will tend to grow and amplify themselves to the extent of causing a significant negative impact on the organizational achievement [4].

A limitation of the present study includes the lack of an observational part of the trainees practice and performance in their working health facility that usually affects quality of tests in the laboratory. On the other hand, this study did not address the result level of Kirkpatrick model that investigates the total training costs against it benefits. It shows the need to study further at a deeper level to get a realistic picture of APHI training program effectiveness.

\section{Conclusion And Recommendations}

Generally speaking, the laboratory in-service training services in Amhara Public Health Institute were marginally effective with its own limitations. To meet its overall organizational objective, the effectiveness of training programs could be regularly monitored and evaluated based on a standard set of training performance indicators. Furthermore, training organizers should utilize lessons learned /feedbacks in this study to create a conducive and appropriate environment for learning which improves the quality of training service.

\section{Abbreviations}

APHI: Amhara Public Health Institute Dessei Branch

\section{Declarations}

\section{Ethical approval and consent to participate}


Ethical approval was obtained from Institutional Review Committee of Amhara Public Health Institute. Formal letter was given to each health facilities to obtain permission and cooperation. After briefing the purpose of the study oral consent was obtained from each participant.

\section{Consent for publication}

Not applicable

\section{Availability of data and materials}

All relevant data are within the manuscript and its Supporting Information files.

\section{Competing interests}

We declare no competing interests.

\section{Funding}

Funding was not received from any organization, but APHI has covered data enumeration cost.

\section{Authors' contributions}

SL designed the study, participated in and monitored the data collection process, analysed the data, and wrote the first draft of the manuscript. TA participated in the design and analysis of the study. He also involved in first draft writing, reviewing and modifying the drafts of the manuscript. The rest author's had equal contribution in the design and data collection stages of the study. All the authors have read and approved the final version of the manuscript.

\section{Acknowledgments}

We acknowledge Amhara Public Health Institute Dessie Branch for covering data enumeration expense. We also appreciate the study participants for their willingness to to participate in the study.

\section{References}

1. USAID ASSIST Project. A global improvement framework for health worker in-service training [Internet]. 2015. Available: https://www.usaidassist.org.

2. World Health Organization. Transforming and scaling up health professionals' education and training: World Health Organization guidelines 2013.

3. Ethiopian Ministry Of Health. Health Sector Transformation Plan. 2015. 
4. International Atomic Energy Agency. Means of evaluating and improving the effectiveness of training of nuclear power plant personnel. 2003.

5. Kaye Alvarez, Eduardo Salas CMG. An Integrated Model of Training Evaluation and Effectiveness. Hum Resour Dev Rev. 2004;3:385-416. doi:10.1177/1534484304270820.

6. Ministry of Interior and Japan International Cooperation Agency. Manual on Training Evaluation.

7. Ethiopian Standards Agency. Advanced Medical Laboratory Requirements. 2012.

8. The Lewin Group. Laboratory Medicine: A National Status Report. 2008.

9. Kebede F, Asres A, Gutema K, Wuliji T. 2012. Towards a National In-service Training Strategy. Workshop Report. Published by the USAID Health Care Improvement Project.

10. Lena Swedberg RN, Hans Michelsen EH, Chiriac IH. On-the-job training makes the difference: healthcare assistants ' perceived competence and responsibility in the care of patients with home mechanical ventilation. 2015; doi:10.1111/scs.12173.

11. Council of the Amhara regional state. Amhara Public Health Institute establishment, proclamation No. 138/2016. 2016.

12. Amhara Public Health Institute. Medical laboratory departement working guideline (unpublished work). 2018.

13. Sally Khalil. The Evaluation of DEMEC Training Program Effectiveness by Using The eQvet-us Model. 2017; 182-198.

14. Rajapakse BN, Neeman TDA. The Effectiveness of a 'Train the Trainer' Model of Resuscitation Education for Rural Peripheral Hospital Doctors in Sri Lanka. PLoS One. 2013;8:1-16. doi:10.1371/journal.pone.0079491.

15. Abdel-All M, Putica B, Praveen D, et al. Effectiveness of community health worker training programmes for cardiovascular disease management in low-income and middle-income countries: A systematic review. BMJ Open. 2017;7:1-11. doi:10.1136/bmjopen-2016-015529.

16. Opiyo N, English M. In-service training for health professionals to improve care of seriously ill newborns and children in low-income countries. Cochrane Database Syst Rev. 2015;2015. doi:10.1002/14651858.CD007071.pub3. 